\title{
ANALISIS FUNDAMENTAL DAN NILAI SAHAM DENGAN METODE PRICE EARNING RATIO (PER)DAN PRICE TO BOOKVALUE (PBV) DALAM KEPUTUSAN INVESTASI (PERUSAHAAN SEMEN YANG TERDAFTAR DI BURSA EFEK INDONESIA (BEI) PERIODE 2016-2018)
}

\author{
Niar Berlian ${ }^{1}$ \\ Nindi Vaulia Puspita ${ }^{2}$ \\ Kartika Yuliari $^{3}$ \\ ${ }^{1,2,3}$ Universitas Kadiri \\ email : nindi.vaulia@unik-kediri.ac.id
}

\begin{abstract}
ABSTRAK
Penelitian bertujuan untuk mengetahui hasil analisis fundamental dan harga saham perusahaan semen yang terdaftar di Bursa Efek Indonesia (BEI) pada tahun 2016-2018 dengan menggunakan metode Price Earning Ratio (PER) dan Price to Bookvalue (PBV) untuk keputusan investasi. Digunakan 4 sampel perusahaan yaitu berkaitan dengan perusahaan semen. Analisis fundamental dengan penjabaran ekonomi makro dan lapotan keuangan, untuk mengetahui nilai saham. Dilakukan metode Price Earning Ratio (PER) dan Price to Bookvalue (PBV) untuk melakukan keputusan berinvestasi. Hasil penelitian yaitu keputusan berinvestasi metode Price Earning Ratio (PER) pada T Semen Baturaja Tbk, PT Holcim Indonesia Tbk dan PT Semen IndonesiaTbk dan metode Price to Bookvalue (PBV) pada PT Holcim Indonesia Tbk dan PT Semen IndonesiaTbk, masing - masing pada kondisi saham undervalued. Kesimpulan yang didapatkan perusahan tersebut dapat digunakan untuk keputusan berinvestasi.
\end{abstract}

Kata Kunci :Price Earning Ratio (PER),Price to Bookvalue (PBV), Undervalued

\section{ABSTRACT}

The study aims to determine the results of fundamental analysis and stock prices of cement companies listed on the Indonesia Stock Exchange (IDX) in 2016-2018 using the Price Earning Ratio (PER) and Price to Bookvalue (PBV) methods for investment decisions. We used 4 sample companies, namely those related to cement companies. Fundamental analysis with the translation of macroeconomics and financial reports, to determine the value of shares. Price Earning Ratio (PER) and Price to Book value (PBV) methods are used to make investment decisions. The results of the research are the decision to invest in the Price 
Earning Ratio (PER) method at T Semen Baturaja Tbk, PT Holcim Indonesia Tbk and PT Semen Indonesia Tbk and the Price to Book value (PBV) method at PT Holcim Indonesia Tbk and PT Semen Indonesia TBk, respectively on stock conditions. undervalued. The conclusions obtained by these companies can be used for investment decisions.

Keyswords : Price Earning Ratio, Price to Book Value, Undervalued

\section{PENDAHULUAN}

Investasi menurut (Hartono, 2017) merupakan penangguhan konsumsi di masa saat ini untuk era yang akan datang dengan memasukkan modal tertentu. Menurut (Ghozi Faiz Alhakim, 2018) menjelaskan bahwa pasar modal adalah salah satu alternatif investasi yang lumayan menjanjikan, meski investasi tidak dapat dipisahkan dari risiko yang mungkin suatu saat dihadapi. Berkembangnya pasar modal di Indonesia bisa kita lihat dari pergerakan Indeks Harga Saham Gabungan (IHSG) yang mengalami pertumbuhan dari tahun ke tahun.

Secara umum terdapat dua pendekatan untuk analisis fundamental, antara lain menggunakan metode Price Earning Ratio (PER) dan Price to Bookvalue (PBV).

Industri semen menjadi pilihan peneliti sebagai opsi penelitian, sebab pemerintah telah mengedepankan pembangunan infrastruktur di Indonesia. Salah satu bahan baku yang penting di gunakan adalah semen, karena semua jenis pembangunan infrastruktur pasti memerlukan semen, sehingga keperluan semen di Indonesia saat ini semakin mengalami penambahan.

\section{Rumusan Masalah}

Berdasarkan latar belakang yang telah dijelaskan diatas, dapat kita nyatakan rumusan masalah dalam penilitian ini adalah "Bagaimana analisis fundamental untuk berinvestasi pada perusahaan semen yang terdaftar di Bursa Efek Indonesia pada tahun 2016-2018 dengan menggunakan metode PER dan PBV?" Dan "Bagaimana harga saham perusahaan semen yang terdaftar di Bursa Efek Indonesia pada tahun 2016-2018 menggunakan metode Price Earning Ratio (PER) dan Price to Bookvalue (PBV) untuk keputusan investasi?"

\section{Tujuan Penelitian}

Untuk menjabarkan bagaimana hasil analisis fundamental dan menjabarkan bagaimana hasil analisis harga saham perusahaan semen yang terdaftar di Bursa Efek Indonesia (BEI) pada tahun 2016-2018 dengan menggunakan metode Price Earning Ratio (PER) dan Price to Bookvalue (PBV) untuk keputusan investasi.

\section{TINJAUAN PUSTAKA}

Kinerja perusahaan merupakan hasil dari suatu proses bisnis perusahaan yang menunjukkan bahwa sebuah keberhasilan suatu perusahaan dapat diukur dengan menggunakan informasi keuangan maupun non keuangan (Hidayat, 2018).

Undang-Undang Nomor 8 Tahun 1995 tentang Pasar Modal memberikan pengertian yang lebih spesifik mengenai pasar modal, yaitu "Kegiatan yang bersangkutan dengan Penawaran Umum dan perdagangan Efek, Perusahaan 
Publik yang berkaitan dengan Efek yang diterbitkannya, serta lembaga dan profesi yang berkaitan dengan Efek".

Investasi adalah komitmen atas sejumlah dana atau sumber daya lainnya yang dilakukan pada saat ini, dengan tujuan memperoleh sejumlah keuntungan di masa datang (Tandelilin, 2017:2).

Analisis fundamental merupakan strategi analisis dengan menggunakan nilai intrinsik saham menggunakan data keuangan perusahaan tersebut Wulandari, (2016). Menurut (Hawtan, 2010) indikator dalam ekonomi makro yang bisa mempengaruhi pergerakan harga saham yaitu Produk Domestik Bruto (PDB), tingkat inflasi, tingkat suku bunga dan nilai tukar rupiah. Sedangkan analisis peusahaan dilakukan dengan menggunakan analisis laporan keuangan menggunakan rasio Aktivitas, Likuiditas, Solvabilitas dan Profitabilitas.

Analisis Ekonomi Makro dilakukan dengan melihat kondisi perekonomian secara makro untuk mendapatkan penilaian perekonomian secara umum dengan tujuan untuk mengetahui pengaruhnya terhadap kondisi pasar modal khususnya pergerakan harga saham (Hawtan, 2010). Analisis ini dilakukan dengan menggunakan indikator Produk Domestik Bruto (PDB), Tingkat Inflasi, Tingkat Suku Bunga, dan Nilai Tukar Rupiah.

Analisis Laporan Keuangan merupakan hal yang penting untuk dilakukan karena untuk mengetahui seberapa besar kelemahan dan kekuatan suatu perusahaan (Ghozi Faiz Alhakim, 2018). Rasio yang digunakan antara lain yaitu Rasio Aktifitas, Rasio Likuiditas, Rasio Solvabilitas dan Rasio Profitabilitas.

Penilaian Harga Saham dilakukan melalui valuasi. Kurniawan (2017) valuasi adalah metode menentukan nilai wajar atau nilai instrinsik dari suatu saham.Valuasi harga saham dapat dilakukan menggunakan Relative Valuation (Hidayat, 2018). Metode pendekatan valuasi yang menggunakan revaluation valuation merupakan penggunaan penilaian dari asset yang sama dan bagaimana menggunakan asset yang sama di dalam pasar.

Metode valuasi pada penelitian ini menggunakan relative valuation dengan Price earning ratio (PER) dan Price to Bookvalue (PBV).

\section{METODE PENELITIAN}

\section{Sampel Penelitian}

Sampel pada penelitian ini adalah perusahaan semen yang terdaftar pada Bursa Efek Indonesia (BEI) tahun 2016-2018 antara lain yaitu PT Indocement Tunggal Perkasa, Tbk (INTP), PT Semen Indonesia, Tbk (SMGR), PT Semen Baturaja, Tbk (SMBR), PT Solusi Bangun Indonesia, Tbk (SMCB).

\section{Metode Pengambilan Sampel}

Teknik pengambilan sampel dalam penelitian ini yaitu menggunakan teknik purposive sampling.

\section{Cara Pengukuran dan Definisi Operasional}

Cara pengukuran dalam penelitian ini yaitu dengan menggunakan pendekatan analisis fundamental, yaitu dengan analisis terhadap ekonomi makro dan laporan keuangan untuk mengetahui nilai intrinsik suatu saham, nilai intrinsik dihitung dengan menggunakan Price Earning Ratio (PER) dan Price to Bookvalue (PBV). Sedangkan Definisi Operasional dalam penelitian ini adalah Produk 
Domestik Bruto (PDB), Tingkat inflasi, Tingkat suku bunga dan Nilai tukar rupiah untuk Ekonomi makro. Rasio Aktivitas, Likuiditas, Solvabilitas dan Profitabilitas untuk Laporan Keuangan. Dan Price Earning Ratio (PER) dan Price to Bookvalue (PBV) untuk mengukur valuasi harga saham.

\section{Metode Pengumpulan Data}

Metode pengumpulan data yang diambil dalam penelitian ini yaitu metode dokumentasi, dokumentasi dalam penelitian ini digunakan untuk mengumpulkan data adalah :

1. Data Produk Domestik Bruto (PDB) tahun 2016 - 2018 yang dikeluarkan oleh Badan Pusat Statistik (BPS).

2. Data Inflasi, tingkat suku bunga dan nilai tukar rupiah tahun 2016 - 2018 yang dipublikasikan oleh Bank Indonesia (BI)

3. Laporan Keuangan tahunan perusahaan PT Indocement Tunggal Perkasa, Tbk, PT Semen Baturaja, Tbk, PT Holcim Indonesia, Tbk dan PT Semen Indonesia, Tbk tahun 2016-2018 yang diterbitkan oleh Bursa Efek Indonesia (BEI).

\section{Metode Analisis Data}

Dalam penelitian ini metode yang digunakan untuk menganalisis data adalah menggunakan analisis fundamental. Nilai intrinsik saham dihitung dengan menggunakan Price Earning Ratio (PER) dan Price to Bookvalue (PBV) (Fuady, 2014).

\section{HASIL DAN PEMBAHASAN}

\section{Analisis Ekonomi Makro}

Pertumbuhan ekonomi global pada tahun 2016 masih tidak merata dan belum kuat. pertumbuhan ekonomi global pada tahun 2016 hanya mencapai 3,1\%. Pada tahun 2017 ekonomi global berhasil tumbuh 3,8\% setelah menunjukkan perfoma melemah tiga tahun sebelumnya. Pertumbuhan ekonomi global pada tahun 2018 melambat dengan pertumbuhan antar negara yang tidak merata. Ekonomi dunia tercatat tumbuh sebesar $3,7 \%$ pada tahun 2018 , sedikit melambat dibandingkan dengan pertumbuhan pada tahun 2017 yang sebesar 3,8\%.

\section{Produk Domestik Bruto (PDB)}

Perekonomian Indonesia mempunyai pertumbuhan setiap tahun yang masing-masing sebesar 5,03\% (2016), 5,07\% (2017), 5,17\% (2018), hal ini menandakan bahwa setiap lapangan usaha tidak selalu memiliki angka kontribusi yang konstan atas PDB, hal ini didasarkan pada kondisi perekonomian yang turut mempengaruhi laju setiap lapangan usaha dalam menghasilkan pendapatan.

Produk Domestik Bruto Atas Dasar Berlaku (Triliun Rupiah)

\begin{tabular}{|c|c|c|c|c|}
\hline \multirow{2}{*}{ No } & Lapangan Usaha & \multicolumn{3}{|c|}{ Tahun } \\
\cline { 3 - 5 } & & $\mathbf{2 0 1 6}$ & $\mathbf{2 0 1 7}$ & $\mathbf{2 0 1 8}$ \\
\hline 1 & Pertanian, Kehutanan, dan Perikanan & $1.671,6$ & $1.787,3$ & $1.900,4$ \\
\hline
\end{tabular}




\begin{tabular}{|c|l|c|c|c|}
\hline 2 & Pertambangan dan Penggalian & 890,9 & $1.029,6$ & $1.199,0$ \\
\hline 3 & Industri Pengolahan & $2.545,2$ & $2.739,7$ & $2.947,3$ \\
\hline 4 & Pengadaan Listrik dan Gas & 142,3 & 162,4 & 176,4 \\
\hline 5 & $\begin{array}{l}\text { Pengadaan Air, Pengelolaan Sampah, } \\
\text { Limbah dan Daur Ulang }\end{array}$ & 8,9 & 9,4 & 10,0 \\
\hline 6 & Konstruksi & $1.287,6$ & $1.410,5$ & $1.562,3$ \\
\hline 7 & $\begin{array}{l}\text { Perdagangan Besar dan Eceran; } \\
\text { Reparasi Mobil dan Sepeda Motor }\end{array}$ & $1.635,4$ & $1.768,9$ & $1.931,9$ \\
\hline 8 & Transportasi dan Pergudangan & 645,0 & 735,2 & 797,3 \\
\hline 9 & $\begin{array}{l}\text { Penyediaan Akomodasi dan Makan } \\
\text { Minum }\end{array}$ & 363,1 & 386,9 & 412,5 \\
\hline 10 & Informasi dan Komunikasi & 449,2 & 513,7 & 559,1 \\
\hline 11 & Jasa Keuangan dan Asuransi & 520,2 & 571,2 & 616,3 \\
\hline 12 & Real Estate & 350,5 & 382,5 & 406,6 \\
\hline 13 & Jasa Perusahaan & 211,6 & 238,2 & 267,1 \\
\hline 14 & $\begin{array}{l}\text { Administrasi Pemerintahan, Pertahanan } \\
\text { dan Jaminan Sosial Wajib }\end{array}$ & 476,5 & 498,2 & 541,7 \\
\hline 15 & Jasa Pendidikan & 417,4 & 446,3 & 482,1 \\
\hline 16 & Jasa Kesehatan dan Kegiatan Sosial & 132,1 & 144,6 & 157,9 \\
\hline 17 & Jasa lainnya & 211,4 & 239,3 & 268,6 \\
\hline Nilai Tambah Bruto Atas Harga Dasar & $\mathbf{1 1 . 9 5 8 , 9 0}$ & $\mathbf{1 3 . 0 6 3 , 9}$ & $\mathbf{1 4 . 2 3 6 , 5}$ \\
\hline $\begin{array}{l}\text { Pajak Dikurangi Subsidi Atas Harga } \\
\text { Produk }\end{array}$ & $\mathbf{4 4 2 , 8 0}$ & $\mathbf{5 2 3 , 3}$ & $\mathbf{6 0 0 , 9}$ \\
\hline Produk Domestik Bruto & $\mathbf{1 2 . 4 0 1 , 7 0}$ & $\mathbf{1 3 . 5 8 7 , 2}$ & $\mathbf{1 4 . 8 3 7 , 4}$ \\
\hline Laju Pertumbuhan Ekonomi ( Dalam \% ) & $\mathbf{5 , 0 3}$ & $\mathbf{5 , 0 7}$ & $\mathbf{5 , 1 7}$ \\
\hline Sumb : Ban & $2016-2018)$ & & \\
\hline
\end{tabular}

Sumber : Badan Pusat Statistik (BPS) Tahun 2016-2018).

Berdasarkan tabel diatas dapat kita ketahui bahwa sektor kontruksi mengalami peningkatan setiap tahunnya, 1.287,6 Triliun pada tahun 2016, 1.410,5 Triliun pada tahun 2017 dan 1.562,3 Triliun pada tahun 2018. Ini menandakan bahwa sektor kontruksi merupakan sektor yang layak menjadi tujuan investasi.

\begin{tabular}{|l|l|}
\hline Tahun & Inflasi \\
\hline 2016 & 3,02 \\
\hline 2017 & 3,61 \\
\hline
\end{tabular}




\section{\begin{tabular}{|l|l}
2018 & 3,13
\end{tabular}}

Sumber : Badan Pusat Statistik (BPS) Tahun 2016-2018.

Sumbangan Kelompok Pengeluaran Terhadap Inflasi Tahun 2016-2018 (dalam \%) tahun 2016 inflasi tertinggi disumbangkan oleh kelompok bahan makanan dengan inflasi yakni 1,21\%. Penyumbang inflasi terbesar di tahun 2017 adalah kelompok perumahan, air, listrik, gas dan bahan bakar dengan nilai andil sebesar 1,24\%. Pada tahun 2018 penyumbang inflasi terbesar merupakan kelompok bahan makanan yakni sebesar $1,45 \%$.

\section{Tingkat Suku Bunga}

BI Rate tahun 2016-2018

\begin{tabular}{|l|c|c|c|}
\hline \multirow{2}{*}{\multicolumn{1}{c|}{ Bulan }} & \multicolumn{3}{c|}{ Tahun } \\
\cline { 2 - 4 } & $\mathbf{2 0 1 6}$ & $\mathbf{2 0 1 7}$ & $\mathbf{2 0 1 8}$ \\
\hline Januari & $7,25 \%$ & $4,75 \%$ & $4,25 \%$ \\
\hline Februari & $7,00 \%$ & $4,75 \%$ & $4,25 \%$ \\
\hline Maret & $6,75 \%$ & $4,75 \%$ & $4,25 \%$ \\
\hline April & $6,75 \%$ & $4,75 \%$ & $4,25 \%$ \\
\hline Mei & $6,75 \%$ & $4,75 \%$ & $4,75 \%$ \\
\hline Juni & $6,50 \%$ & $4,75 \%$ & $5,25 \%$ \\
\hline Juli & $6,50 \%$ & $4,75 \%$ & $5,25 \%$ \\
\hline Agustus & $5,25 \%$ & $4,50 \%$ & $5,50 \%$ \\
\hline September & $5,00 \%$ & $4,25 \%$ & $5,75 \%$ \\
\hline Oktober & $4,75 \%$ & $4,25 \%$ & $5,75 \%$ \\
\hline November & $4,75 \%$ & $4,25 \%$ & $6,00 \%$ \\
\hline Desember & $4,75 \%$ & $4,25 \%$ & $6,00 \%$ \\
\hline Bank Indon
\end{tabular}

Sumber : Bank Indonesia (BI) Tahun 2016-2018

Bank Indonesia pada 14 Januari 2016 menurunkan suku bunga acuan (BI Rate) sebesar 25 bps menjadi 7,25\%. BI menyatakan ruang pelonggaran kebijakan moneter semakin terbuka dan meredanya ketidakpastian pasar pasca kenaikan Fed Fund Rate pada Desember 2015. Pada awal tahun 2017, BI tetap mempertahankan suku bunga acuan sebesar $4,75 \%$, keputusan tersebut akan menjaga stabilitas makro ekonomi dan sistem keuangan Indonesia. Pada tahun 2018, periode Januari hingga April BI tetap mempertahankan suku bunga acuan sebesar 4,25\%. Kebijakan tersebut konsisten dengan upaya menjaga stabilitas makro ekonomi dan sistem keuangan serta turut mendukung pemulihan ekonomi domestik.

\section{Nilai Tukar Rupiah}

Nilai tukar rupiah pada 2016 secara umum bergerak dalam arah menguat disertai volatilitas yang menurun. Nilai tukar rupiah menguat $2,3 \%$ (yoy) hingga ditutup pada level Rp13.473 per dolar AS di akhir 2016. Volatilitas rupiah juga menurun dari $11,1 \%$ pada 2015 menjadi sebesar $8,4 \%$. 
Nilai tukar rupiah pada tahun 2017 menunjukkan adanya kestabilan dan cenderung mengalami penguatan. Secara rata-rata, nilai tukar rupiah hanya melemah dari Rp 13.473 pada 2016 menjadi Rp 13.568 pada 2017.

Nilai tukar rupiah terhadap dolar Amerika Serikat mengalami pelemahan selama tahun 2018. Bank Indonesia mengungkapkan tekanan terhadap rupiah kembali meningkat seiring kuatnya ketidakpastian pasar keuangan global, hal ini memicu penguatan dolar AS secara meluas. Adapun pada November 2018, rupiah balik arah menguat pada level Rp 14.891. pada pertengahan November hingga Desember akhir, rupiah naik turun pada level Rp 14.300 hingga Rp 14.500 per USD.

\section{Analisis Laporan Keuangan Rasio Aktifitas}

Data Rasio Inventory Turnover Tahun 2016-2018

\begin{tabular}{|l|l|l|l|}
\hline Nama Perusahaan & 2018 & 2017 & 2016 \\
\hline PT Indocement Tunggal Perkas Tbk & $8.3 \mathrm{x}$ & $8.1 \mathrm{x}$ & $8.7 \mathrm{x}$ \\
\hline PT Semen baturaja Tbk & $6.9 \mathrm{x}$ & $7.7 \mathrm{x}$ & $8.8 \mathrm{x}$ \\
\hline PT Holcim Indonesia Tbk & $10.7 \mathrm{x}$ & $10.6 \mathrm{x}$ & $17.1 \mathrm{x}$ \\
\hline PT Semen Indonesia Tbk & $8.6 \mathrm{x}$ & $7.6 \mathrm{x}$ & $9.7 \mathrm{x}$ \\
\hline
\end{tabular}

Sumber : Laporan Keuangan Tahunan PT Indocement Tunggal Perkasa Tbk, PT Semen Baturaja Tbk, PT Holcim Indonesia Tbk dan PT Semen Indonesia Tbk Tahun 2016-2018 (data diolah peneliti)

Pada tahun 2016 rasio Inventory Turn Over perusahaan PT Indocement Tunggal Perkasa Tbk adalah sebesar 8.7x, tahun 2017 8.1x dan pada tahun 2018 $8.3 x$. Terjadi peningkatan rasio yang menandakan bahwa perputaran persediaan yang ada semakin cepat dalam setiap tahunnya.

PT Semen Baturaja Tbk pada tahun 2016 rasio Inventory Turnover perusahaan adalah sebesar 8.8x, tahun 2017 7.7x dan pada tahun 2018 6.9x. Terjadi peningkatan rasio yang menandakan bahwa perputaran persediaan yang ada semakin cepat dalam setiap tahunnya.

Pada tahun 2016 rasio Inentory Turnover perusahaan PT Holcim Indonesia Tbk adalah sebesar 17.1x, tahun 2017 10.6x dan pada tahun 2018 10.7x. Terjadi peningkatan rasio yang menandakan bahwa perputaran persediaan yang ada semakin cepat setiap tahunnya.

PT Semen Indonesia Tbk pada tahun 2016 rasio Inventory Turn Over perusahaanya yaitu sebesar 9.7x, tahun 2017 7.6x dan pada tahun 2018 8.6x. terjadi peningkatan rasio yang menandakan bahwa perputaran persediaan yang ada semakin cepat dalam setiap tahunnya.

\section{Rasio Likuiditas}

Data Current Ratio Tahun 2016-2018

\begin{tabular}{|l|l|l|l|}
\hline Nama Perusahaan & 2018 & 2017 & 2016 \\
\hline PT Indocement Tunggal Perkasa Tbk & $3.13 \mathrm{x}$ & $3.70 \mathrm{x}$ & $4.52 \mathrm{x}$ \\
\hline PT Semen baturaja Tbk & $2.13 \mathrm{x}$ & $1.67 \mathrm{x}$ & $2.86 \mathrm{x}$ \\
\hline PT Holcim Indonesia Tbk & $0.26 \mathrm{x}$ & $0.54 \mathrm{x}$ & $0.45 \mathrm{x}$ \\
\hline
\end{tabular}




\begin{tabular}{|l|l|l|l|}
\hline PT Semen Indonesia Tbk & $1.95 \mathrm{x}$ & $1.56 \mathrm{x}$ & $1.27 \mathrm{x}$ \\
\hline
\end{tabular}

Sumber : Laporan Keuangan Tahunan PT Indocement Tunggal Perkasa Tbk, PT Semen Baturaja Tbk, PT Holcim Indonesia Tbk dan PT Semen Indonesia Tbk Tahun 2016-2018 (data diolah peneliti)

Pada tahun 2016 current ratio PT Indocement Tunggal Perkasa Tbk berada pada 4.52x, tahun 2017 3.70x dan pada tahun 2018 3.13x. Perubahan current ratio dari tahun 2016 hingga 2018 menunjukkan penurunan, sehingga pemanfaatan kewajibannya semakin kecil dari tahun ke tahun.

Current Ratio PT Semen Baturaja Tbk pada tahun 2016 adalah 2.86x, tahun 2017 1.67x dan pada tahun 2018 2.13x. Meskipun terjadi penurunan pada tahun 2017 sebesar 1.67x, namun pada tahun 2018 kembali mengalami kenaikan. Hal ini menunjukkan bahwa rasio current ratio perusahaan mempunyai kemampuan untuk menutupi kewajiban tidak lancarnya dengan aset lancarnya.

Pada tahun 2016 current ratio PT Holcim Indonesia Tbk adalah $0.45 \mathrm{x}$, tahun 2017 mengalami kenaikan sebesar 0.54x dan pada tahun 2018 mengalami penurunan $0.26 \mathrm{x}$, sehingga pemanfaatan kewajibannya semakin kecil.

Rasio current ratio PT Semen Indonesia Tbk pada tahun 2016 adalah 1.27x, tahun 2017 1.56x dan tahun 2018 1.95x. Hal ini menunjukkan bahwa perusahaan mempunyai kemampuan untuk menutupi kewajiban tidak lancarnya dengan aset lancarnya yang semakin naik setiap tahunnya.

\section{Rasio Solvabilitas}

Debt to Asset Ratio (DAR)

Data Debt to Asset Ratio Tahun 2016-2018

\begin{tabular}{|l|l|l|l|}
\hline Nama Perusahaan & 2018 & 2017 & 2016 \\
\hline PT Indocement Tunggal Perkasa Tbk & $0.16 \mathrm{x}$ & $0.14 \mathrm{x}$ & $0.13 \mathrm{x}$ \\
\hline PT Semen baturaja Tbk & $0.37 \mathrm{x}$ & $0.32 \mathrm{x}$ & $0.28 \mathrm{x}$ \\
\hline PT Holcim Indonesia Tbk & $0.65 \mathrm{x}$ & $0.63 \mathrm{x}$ & $0.59 \mathrm{x}$ \\
\hline PT Semen Indonesia Tbk & $0.36 \mathrm{x}$ & $0.38 \mathrm{x}$ & $0.30 \mathrm{x}$ \\
\hline
\end{tabular}

Sumber : Laporan Keuangan Tahunan PT Indocement Tunggal Perkasa Tbk, PT Semen Baturaja Tbk, PT Holcim Indonesia Tbk dan PT Semen Indonesia Tbk Tahun 2016-2018 (data diolah peneliti)

Pada tahun 2016 Debt to Asset Ratio PT Indocement Tunggal Perkasa Tbk adalah $0.13 \mathrm{x}$, tahun 2017 0.14x dan pada tahun 2018 0.16x. Hal ini baik karena rasio DAR berada dibawah $0.5 x$ dan terus membaik setiap tahunnya.

Pada tahun 2016 Debt to Asset Ratio PT Semen Baturaja Tbk adalah $0.28 x$, tahun $20170.32 x$ dan pada tahun $20180.37 x$. Hal ini baik karena rasio DAR berada dibawah $0.5 \mathrm{x}$ dan terus membaik setiap tahunnya.

Pada tahun 2016 Debt to Asset Ratio PT Holcim Indonesia Tbk adalah 0.59x, tahun 2017 0.63x dan pada tahun 2018 0.65x. Hal ini kurang baik karena rasio DAR berada diatas $0.05 x$, sehingga perusahaan semakin banyak memenuhi kewajibannya dengan aktiva yang dimilikinya.

Pada tahun 2016 Debt to Asset Ratio PT Semen Indonesia Tbk adalah 0.30x, tahun 2017 0.38x dan pada tahun 2018 0.36x. Hal ini baik karena rasio DAR berada dibawah $0.5 \mathrm{x}$ dan terus membaik setiap tahunnya. 
Debt to Equity Ratio (DER)

Data Debt to Equity Ratio Tahun 2016-2018

\begin{tabular}{|l|l|l|l|}
\hline Nama Perusahaan & 2018 & 2017 & 2016 \\
\hline PT Indocement Tunggal Perkasa Tbk & $0.19 \mathrm{x}$ & $0.17 \mathrm{x}$ & $0.15 \mathrm{x}$ \\
\hline PT Semen baturaja Tbk & $0.59 \mathrm{x}$ & $0.48 \mathrm{x}$ & $0.39 \mathrm{x}$ \\
\hline PT Holcim Indonesia Tbk & $1.91 \mathrm{x}$ & $1.72 \mathrm{x}$ & $1.45 \mathrm{x}$ \\
\hline PT Semen Indonesia Tbk & $0.56 \mathrm{x}$ & $0.63 \mathrm{x}$ & $0.44 \mathrm{x}$ \\
\hline
\end{tabular}

Sumber : Laporan Keuangan Tahunan PT Indocement Tunggal Perkasa Tbk, PT Semen Baturaja Tbk, PT Holcim Indonesia Tbk dan PT Semen Indonesia Tbk Tahun 2016-2018 (data diolah peneliti)

Pada tahun 2016 Debt to Equity Ratio PT Indocement Tunggal Perkasa Tbk adalah 0.15x, tahun $20170.17 x$ dan pada tahun $20180.19 x$. Hal tersebut menunjukan keberhasilan perusahaan meningkatkan ekuitas perusahaan dari hasil pendanaan internal, baik hasil operasional perusahaan maupun peningkatan modal dari pemegang saham. Dengan semakin kecilnya debt to equity ratio maka biaya modal menjadi semakin kecil.

Pada tahun 2016 Debt to Equity Ratio PT Semen Baturaja Tbk adalah 0.39x, tahun $20170.48 x$ dan pada tahun 2018 0.59x. Hal tersebut menunjukan keberhasilan perusahaan meningkatkan ekuitas perusahaan dari hasil pendanaan internal, baik hasil operasional perusahaan maupun peningkatan modal dari pemegang saham. Dengan semakin kecilnya debt to equity ratio maka biaya modal menjadi semakin kecil.

Pada tahun 2016 Debt to Equity Ratio PT Holcim Indonesia Tbk adalah $1.45 x$, tahun 2017 1.72x dan pada tahun 2018 1.91x. Hal ini kurang baik bagi perusahaan, karena semakin tinggi DER maka kewajiban lebih besar terhadap pemegang saham.

Pada tahun 2016 Debt to Equity Ratio PT Semen Indonesia Tbk adalah 0.44x, tahun 2017 0.63x dan pada tahun 2018 0.56x. Hal tersebut menunjukan keberhasilan perusahaan meningkatkan ekuitas perusahaan dari hasil pendanaan internal, baik hasil operasional perusahaan maupun peningkatan modal dari pemegang saham. Dengan semakin kecilnya debt to equity ratio maka biaya modal menjadi semakin kecil.

\section{Rasio Profitabilitas}

Data Rasio Gross Profit Margin Tahun 2016-2018

\begin{tabular}{|l|l|l|l|}
\hline Nama Perusahaan & 2018 & 2017 & 2016 \\
\hline PT Indocement Tunggal Perkasa Tbk & $28.76 \%$ & $34.70 \%$ & $41.22 \%$ \\
\hline PT Semen baturaja Tbk & $35.41 \%$ & $30.47 \%$ & $33.56 \%$ \\
\hline PT Holcim Indonesia Tbk & $15.84 \%$ & $19.98 \%$ & $20.41 \%$ \\
\hline PT Semen Indonesia Tbk & $30.40 \%$ & $28.62 \%$ & $37.71 \%$ \\
\hline
\end{tabular}

Sumber : Laporan Keuangan Tahunan PT Indocement Tunggal Perkasa Tbk, PT Semen Baturaja Tbk, PT Holcim Indonesia Tbk dan PT Semen Indonesia Tbk Tahun 2016-2018 (data diolah peneliti) 
Pada tahun 2016 Gross Profit Margin PT Indocement Tunggal Perkasa Tbk adalah sebesar $41.22 \%$, kemudian mengalami penuruan sebesar $34.70 \%$ dan $28.76 \%$ pada tahun 2017 hingga 2018. Penuruan yang terjadi ini disebabkan oleh meningkatnya beban produksi perusahaan.

PT Semen Baturaja Tbk tahun 2016 memperoleh Gross Profit Margin sebesar 33.56\%, menurun pada tahun 2017 yaitu sebesar $30.47 \%$ dan kemudian meningkat lagi sebesar $35.41 \%$ pada tahun 2018. Penurunan yang terjadi pada tahun 2017 disebabkan oleh meningkatnya biaya produksi perusahaan.

Pada tahun 2016 hingga tahun 2018 PT Holcim Indonesia Tbk Gross Profit Margin mengalami penurunan yang masing-masing sebesar 20.41\%, $19.98 \%$ dan $15.84 \%$. Hal ini disebabkan oleh meningkatnya beban produksi perusahaan.

PT Semen Indonesia Tbk tahun 2016 memperoleh Gross Profit Margin sebesar $37.71 \%$, menurun pada tahun 2017 yaitu sebesar $28.62 \%$ dan kemudian mengalami kenaikan tipis yaitu sebesar $30.40 \%$. Penurunan yang terjadi pada tahun 2017 disebabkan karena meningkatnya beban produksi perusahaan.

Data Rasio Operating Profit Margin 2016-2018

\begin{tabular}{|l|l|l|l|}
\hline Nama Perusahaan & 2018 & 2017 & 2016 \\
\hline PT Indocement Tunggal Perkasa Tbk & $57.59 \%$ & $57.41 \%$ & $23.72 \%$ \\
\hline PT Semen baturaja Tbk & $12.40 \%$ & $12.38 \%$ & $21.57 \%$ \\
\hline PT Holcim Indonesia Tbk & $1.39 \%$ & $0.72 \%$ & $1.19 \%$ \\
\hline PT Semen Indonesia Tbk & $15.90 \%$ & $10.25 \%$ & $20.00 \%$ \\
\hline
\end{tabular}

Sumber : Laporan Keuangan Tahunan PT Indocement Tunggal Perkasa Tbk, PT Semen Baturaja Tbk, PT Holcim Indonesia Tbk dan PT Semen Indonesia Tbk Tahun 2016-2018 (data diolah peneliti)

Pada tahun 2016 Operating Profit Margin PT Indocement Tunggal Perkasa Tbk adalah sebesar 23.72\%. Pada tahun 201757.41 dn pada tahun 2018 adalah sebesar 57.59\%. Dengan Operating Profit Margin yang terus meningkat, menunjukkan bahwa perusahaan mampu untuk mengontrol biaya operasionalnya.

Pada tahun 2016 Operating Profit Margin PT Semen Baturaja Tbk adalah sebesar $21.57 \%$. Pada tahun 2017 mengalami penurunan sebesar $12.38 \%$, namun pada tahun 2018 mengalami kenaikan yang sangat tipis yaitu sebesar $12.40 \%$. Penurunan yang terjadi pada tahun 2017 disebabkan karena perusahaan belum mampu mengendalikan biaya operasionalnya.

Pada tahun 2016 Operating Profit Margin PT Holcim Indonesia Tbk adalah sebesar $1.19 \%$. Sementara pada tahun 2017 mengalami penurunan sebesar $0.72 \%$, kemudian pada tahun 2018 kembali naik sebesar 1.39\%. Dengan Operating Profit Margin yang menurun pada tahun 2017 penyebabnya adalah perusahaan belum mampu mengontrol biaya operasionalnya.

Pada tahun 2016 Operating Profit Margin PT Semen Indonesia Tbk adalah sebesar $20.00 \%$, pada tahun 2017 adalah sebesar $10.25 \%$ sedangkan pada tahun 2018 adalah sebesar 15.90\%. Dengan Operating Profit Margin yang menurun pada tahun 2017 menunjukkan bahwa perusahaan belum mampu mengontrol biaya operasionalnya. 
Data Rasio Net Profit Margin Tahun 2016-2018

\begin{tabular}{|l|l|l|l|}
\hline Nama Perusahaan & $\mathbf{2 0 1 8}$ & $\mathbf{2 0 1 7}$ & $\mathbf{2 0 1 6}$ \\
\hline PT Indocement Tunggal Perkasa Tbk & $07.54 \%$ & $12.89 \%$ & $25.19 \%$ \\
\hline PT Semen baturaja Tbk & $03.81 \%$ & $09.45 \%$ & $17.01 \%$ \\
\hline PT Holcim Indonesia Tbk & $07.52 \%$ & $09.21 \%$ & $03.01 \%$ \\
\hline PT Semen Indonesia Tbk & $10.06 \%$ & $05.93 \%$ & $17.35 \%$ \\
\hline
\end{tabular}

Sumber : Laporan Keuangan Tahunan PT Indocement Tunggal Perkasa Tbk, PT Semen Baturaja Tbk, PT Holcim Indonesia Tbk dan PT Semen Indonesia Tbk Tahun 2016-2018 (data diolah peneliti)

Pada tahun 2016 Net Profit Margin PT Indocement Tunggal Perkasa Tbk adalah sebesar $25.19 \%$ selanjutnya pada tahun 2017 adalah sebesar $12.89 \%$ dan pada tahun 2018 adalah sebesar $07.54 \%$. Terjadinya penurunan laba bersih ini karena meningkatnya biaya lain-lain dari perusahaan.

Pada tahun 2016 Net Profit Margin PT Semen Baturaja Tbk adalah sebesar $17.01 \%$, pada tahun 2017 adalah sebesar $09.45 \%$ dan pada tahun 2018 adalah sebesar $03.81 \%$. Terjadinya penurunan laba bersih pada tahun 2017 hingga 2018 ini disebabkna oleh meningkatnya biaya lain-lain dari perusahaan.

Pada tahun 2016 Net Profit Margin PT Holcim Indonesia Tbk adalah sebesar $03.01 \%$, selanjutnya mengalami kenaikan pada tahun 2017 yaitu sebesar $09.21 \%$ dan pada tahun 2018 mengalami penurunan sebesar $07.52 \%$. Terjadi penurunan laba bersih pada tahun 2018 hal ini dikarenakan meningkatnya biaya lain-lain dari perusahaan.

Pada tahun 2016 Net Profit Margin PT Semen Indonesia adalah sebesar $17.35 \%$, selanjutnya pada tahun 2017 mengalami penurunan yaitu sebesar $05.93 \%$. Kemudian mengalami kenaikan pada tahun 2018 yaitu sebesar $10.06 \%$. Kenaikan yang terjadi pada tahun 2018 disebabkan oleh minimumnya biaya lainlain dari perusahaan.

Data Rasio Return on Asset Tahun 2016-2018

\begin{tabular}{|l|l|l|l|}
\hline Nama Perusahaan & $\mathbf{2 0 1 8}$ & $\mathbf{2 0 1 7}$ & $\mathbf{2 0 1 6}$ \\
\hline PT Indocement Tunggal Perkasa Tbk & $04.12 \%$ & $06.44 \%$ & $12.84 \%$ \\
\hline PT Semen baturaja Tbk & $01.37 \%$ & $02.90 \%$ & $05.93 \%$ \\
\hline PT Holcim Indonesia Tbk & $04.18 \%$ & $04.40 \%$ & $01.44 \%$ \\
\hline PT Semen Indonesia Tbk & $06.03 \%$ & $03.36 \%$ & $10.25 \%$ \\
\hline
\end{tabular}

Sumber : Laporan Keuangan Tahunan PT Indocement Tunggal Perkasa Tbk, PT Semen Baturaja Tbk, PT Holcim Indonesia Tbk dan PT Semen Indonesia Tbk Tahun 2016-2018 (data diolah peneliti)

Pada tahun 2016 Return on Asset PT Indocement Tunggal Perkasa Tbk adalah sebesar 12.84\%, pada tahun 2017 adalah sebesar $06.44 \%$ dan pada tahun 2018 adalah sebesar 04.12\%. Pada tahun 2018 ada penurunan Return on Asset yang terjadi karena penurunan Net Profit Margin pada tahun tersebut.

Pada tahun 2016 Return on Asset PT Semen Baturaja Tbk adalah sebesar 05.93\%, pada tahun 2017 adalah sebesar 02.90\% kemudian pada tahun 2018 
adalah sebesar $01.37 \%$. Penurunan Return on Asset yang terjadi pada tahun 2018 dikarenakan adanya penurunan Net Profit Margin pada tahun tersebut.

Pada tahun 2016 Return on Asset PT Holcim Indonesia Tbk adalah sebesar $01.44 \%$, pada tahun 2017 adalah sebesar $04.40 \%$ dan pada tahun 2018 adalah sebesar 04.18\%. Penurunan Return on Asset yang terjadi pada tahun 2018 dikarenakan adanya penurunan Net Profit Margin pada tahun tersebut.

Pada tahun 2016 Return on Asset PT Semen Indonesia Tbk adalah sebesar 10.25\%, selanjutnya pada tahun 2017 adalah sebesar 3.36\% dan pada tahun 2018 adalah sebesar 06.03\%. Di tahun 2018 mengalami peningkatan Return on Asset dikarenakan adanya peningkatan Net Profit Margin pada tahun tersebut.

Data Rasio Return on Equity Tahun 2016-2018

\begin{tabular}{|l|l|l|l|}
\hline Nama Perusahaan & $\mathbf{2 0 1 8}$ & $\mathbf{2 0 1 7}$ & $\mathbf{2 0 1 6}$ \\
\hline PT Indocement Tunggal Perkasa Tbk & $04.93 \%$ & $07.57 \%$ & $14.81 \%$ \\
\hline PT Semen baturaja Tbk & $02.19 \%$ & $04.30 \%$ & $08.30 \%$ \\
\hline PT Holcim Indonesia Tbk & $12.00 \%$ & $12.17 \%$ & $03.53 \%$ \\
\hline PT Semen Indonesia Tbk & $09.43 \%$ & $05.49 \%$ & $14.83 \%$ \\
\hline
\end{tabular}

Sumber : Laporan Keuangan Tahunan PT Indocement Tunggal Perkasa Tbk, PT Semen Baturaja Tbk, PT Holcim Indonesia Tbk dan PT Semen Indonesia Tbk Tahun 2016-2018 (data diolah peneliti)

Pada tahun 2016 Return on Equity PT Indocement Tunggal Perkasa Tbk adalah sebesar $14.81 \%$, pada tahun 2017 adalah sebesar $07.57 \%$ dan pada tahun 2018 adalah sebesar 04.93\%. Hal ini disebabkan oleh Net Profit Margin pada tahun 2018 menurun yang di ikuti penurunan Equity dari perusahaan.

PT Semen Baturaja Tbk pada tahun 2016 menghasilkan Return on Equity sebesar 08.30\%, pada tahun 2017 adalah sebesar $04.30 \%$ dan pada tahun 2018 adalah sebesar $02.19 \%$. Hal ini disebabkan oleh Net Profit Margin pada tahun 2018 menurun yang di ikuti penurunan Equity dari perusahaan.

Pada tahun 2016 Return on Equity PT Holcim Indonesia Tbk adalah sebesar $03.53 \%$, pada tahun 2017 adalah sebesar $12.17 \%$ dan pada tahun 2018 adalah sebesar $12.00 \%$ Penurunan ini disebabkan oleh menurunnya Net Profit Margin pada tahun tersebut dengan disertai penurunan Equity dari perusahaan.

PT Semen Indonesia Tbk pada tahun 2016 menghasilkan Return on Equity sebesar $14.83 \%$, pada tahun 2017 mengalami penurunan sebesar $05.49 \%$ dan kemudian kembali meningkat pada tahun 2018 yaitu sebesar $09.43 \%$. Peningkatan yang terjadi pada tahun 2018 dikarenakan meningkatnya Net Profit Margin pada tahun tersebut yang juga disertai meningkatnya Equity dari perusahaan.

\section{Penilaian Harga Saham Price Earning Ratio (PER)}

Data Price Earning Ratio (PER) Tahun 2016 - 2018

\begin{tabular}{|l|l|l|l|}
\hline Nama Perusahaan & $\begin{array}{l}\text { PER } \\
\text { Perusahaan }\end{array}$ & $\begin{array}{l}\text { PER } \\
\text { Industri } \\
\text { Semen }\end{array}$ & $\begin{array}{l}\text { Relative } \\
\text { PER }\end{array}$ \\
\hline PT Indocement Tunggal Perkasa Tbk & 59.57 & 28.92 & 2.10 \\
\hline PT Semen Baturaja Tbk & 22.87 & 28.92 & 0.79 \\
\hline
\end{tabular}




\begin{tabular}{|l|l|l|l|} 
PT Holcim Indonesia Tbk & 18.53 & 28.92 & 0.64 \\
\hline PT Semen IndonesiaTbk & 14.83 & 28.92 & 0.51 \\
\hline
\end{tabular}

Sumber: Laporan keuangan perusahaan Tahun 2016-2018 (data diolah peneliti)

Berdasarkan kondisi saham pada 4 Perusahaan tersebut, PT Indocement Tunggal Perkasa Tbk memiliki kondisi saham Overvalue, dikarenakan nilai Relative PE Ratio diatas 1. Sedangkan pada PT Semen Baturaja Tbk, PT Holcim Indonesia Tbk dan PT Semen IndonesiaTbk memiliki kondisi saham Undervalue. Kondisi tersebut dikarenakan nilai Relative Relative PE Ratio dibawah 1.

Price to Book Value (PBV)

Data Price to Bookvalue (PBV) Tahun 2016 - 2018

\begin{tabular}{|l|l|l|l|}
\hline Nama Perusahaan & $\begin{array}{l}\text { PBV } \\
\text { Perusahaan }\end{array}$ & $\begin{array}{l}\text { PBV } \\
\text { Industri } \\
\text { Semen }\end{array}$ & $\begin{array}{l}\text { Relative } \\
\text { PBV }\end{array}$ \\
\hline PT Indocement Tunggal Perkasa Tbk & 2.92 & 2.7 & 1.08 \\
\hline PT Semen Baturaja Tbk & 5 & 2.7 & 1.85 \\
\hline PT Holcim Indonesia Tbk & 0.89 & 2.7 & 0.32 \\
\hline PT Semen IndonesiaTbk & 1.99 & 2.7 & 0.73 \\
\hline
\end{tabular}

Sumber: Laporan keuangan perusahaan Tahun 2016 - 2018(data diolah peneliti)

Berdasarkan metode Price to Book Value, PT Indocement Tunggal Perkasa Tbk memiliki nilai PBV relatif sebesar 1,08, memiliki nilai kondisi saham overvalued. Kemudian pada PT Semen Baturaja Tbk berdasarkan nilai PBV mampu menghargai market value sebesar 1,85, memiliki nilai saham dengan kondisi overvalued. Sedangkan pada PT Holcim Indonesia Tbk dan PT Semen IndonesiaTbk memiliki nilai Relative PBV kurang dari 1 dengan kondisi saham undervalue.

Dari kedua metode untuk melakukan analisis fundamental, metode Price Earning Ratio (PER) memberikan hasil bahwa, PT Semen Baturaja Tbk, PT Holcim Indonesia Tbk dan PT Semen IndonesiaTbk dapat digunakan untuk berinvestasi sampai akhir 2018 karena nilai Relative PER $<1$ dan tepat dijadikan pilihan untuk investasi. Hal ini sejalan dengan penelitian yang dilakukan oleh (Aprilia, Handayani, \& Hidayat, 2016). Sedangkan PT Indocement Tunggal Perkasa Tbk memiliki nilai Relative PER > 1 sampai tahun 2018. Hal tersebut sejalan dengan penelitian yang dilakukan oleh dan belum tepat dijadikan pilihan investasi sebab harga saham yang tinggi dan metode Price to Bookvalue (PBV) memberikan hasil bahwa, PT Indocement Tunggal Perkasa Tbk dan PT Semen Baturaja Tbk belum dapat digunakan untuk berinvestasi karena nilai Relative PBV masing - masing > 1 sampai tahun 2018, sedangkan PT Holcim Indonesia Tbk dan PT Semen IndonesiaTbk dapat digunakan untuk investasi karena nilai Relative PBV masing - masing <1 sampai tauhn 2018.

Berdasarkan metode Price Earning Ratio (PER) keputusan berinvestasi yang tepat dilakukan pada PT Semen Baturaja Tbk, PT Holcim IndonesianTbk dan PT Semen. IndonesiaTbk dan metode Price to Bookvalue (PBV) keputusan berinvestasi yang tepat dilakukan pada PT Holcim Indonesia Tbk dan PT Semen Indonesia Tbk karena memiliki kondisi undevalued pada akhir tahun 2018. Secara 
teori, jika kondisi saham terjadi undevalued akan mengalami peningkatan harga dimasa mendatang, sehingga investor dapat memilih untuk dijadikan pilihan berinvestasi. Hal ini, searah dengan penelitian yang dilakukan oleh (Aprilia et al., 2016).

\section{KESIMPPULAN DAN SARAN}

\section{Kesimpulan}

1. Hasil analisis fundamental perusahaan semen yang terdaftar di Bursa Efek Indonesia (BEI) pada tahun 2016-2018 untuk keputusan investasi dengan metode Price Earning Ratio (PER) memberikan hasil bahwa, PT Semen Baturaja Tbk, PT Holcim Indonesia Tbk dan PT Semen IndonesiaTbk dapat digunakan untuk berinvestasi sampai akhir 2018 karena nilai Relative PER < 1, dan metode Price to Bookvalue (PBV) memberikan hasil bahwa, PT Holcim Indonesia Tbk dan PT Semen IndonesiaTbk dapat digunakan untuk investasi karena nilai Relative PBV masing masing <1 sampai tauhn 2018.

2. Hasil analisis harga saham perusahaan semen yang terdaftar di Bursa Efek Indonesia (BEI) pada tahun 2016-2018 dengan menggunakan metode Price Earning Ratio (PER) dan Price to Bookvalue (PBV) untuk keputusan investasi dengan kondisi saham undevalued pada akhir tahun 2018

\section{Saran}

1. Para calon investor atau investor yang ingin menanamkan modalnya, sebelum menilai dari perbandingan nilai intrinsik dan harga pasarnya, sebaiknya para calon investor atau investor melihat dan menilai data keuangan atau rasio keuangan perusahaan dan memilih berinvestasi pada perusahaan yang sahamnya masuk dalam kategori undervalued dan apabila sudah memiliki saham sebaiknya menjual saham tersebut apabila saham tersebut masuk dalam kategori overvalued.

2. Sebaiknya para calon investor lebih berhati-hati dalam mengambil keputusan investasi dengan mempertimbangkan kondisi internal maupun kondisi eksternal perusahaan. Karena nilai intrinsik saham dalam analisis fundamental dengan pendekatan Price Earning Ratio (PER) dan Price to Book Value (PBV) merupakan hasil dari estimasi yang berisi prediksi tentu mengandung unsur ketidakpastian.

3. Untuk penelitian selanjutnya sebaiknya melakukan penelitian dengan analisis yang lebih panjang waktunya agar menghasilkan hasil yang lebih valid.

\section{DAFTAR PUSTAKA}

Alipudin, A., \& Amelia, D. S. (2017). Pengaruh Fundamental Sebagai Dasar Pengambilan Keputusan Investasi Saham Pada Perusahaan Manufaktur Subsektor Makanan Dan Minuman Yang Terdaftar Di Bursa Efek Indonesia Tahun 2013 - 2015. JIAFE (Jurnal Ilmiah Akuntansi Fakultas Ekonomi), 3(2), 17-31. https://doi.org/10.34204/jiafe.v3i2.702 
Aprilia, A. A. (2016). Analisis Keputusan Investasi Berdasarkan Penilaian Harga Saham ( Studi Menggunakan Analisis Fundamental dengan Pendekatan Price Earing Ratio ( PER ) Pada Saham Sektor Pertambangan yang Listing di BEI Periode 2012-2014 ). 32(1), 58-65.

Aprilia, A. A., Handayani, S. R., \& Hidayat, R. R. (2016). Analisis Keputusan Investasi Berdasarkan Penilaian Harga Saham (Studi Menggunakan Analisis Fundamental dengan Pendekatan Price Earing Ratio (PER) Pada Saham Sektor Pertambangan yang Listing di BEI Periode 2012-2014). Jurnal Administrasi Bisnis S1 Universitas Brawijaya, 32(1), 58-65.

Fuady, F. (2014). Analisis Fundamental Saham Perusahaan Sektor Barang Konsumsi (Consumer Goods) Di Indeks Saham Syariah Indonesia (ISSI) Periode 2011 - 2013 Dengan Metode Top Down Analysis.

Ghozi Faiz Alhakim. (2018). Analisis fundamental perusahaan serta penilaian saham dengan metode. Analisis Fundamental Perusahaan Serta Penilaian Saham Dengan Metode PER Dan PBV.

Hawtan, P. (2010). Analisis Fundamental Dan Teknikal Saham Pt Pp London Sumatra Indonesia,Tbk.

Hidayat, N. U. R. (2018). Analisis Keputusan Investasi Saham Dengan Pendekatan Price Earning Ratio ( Studi Kasus Pada Perusahaan Yang Terdaftar di Jakarta Islamic Index Tahun 2015-2017 ) Skripsi Diajukan Kepada Fakultas Ekonomi dan Bisnis Islam Jurusan Ekonomi Syari’ Ah Fakultas .

Natalia, D. (2019). Analisis Valuasi Saham Menggunakan Pendekatan Dividend Discount Model (Ddm), Price Earning Ratio (PER) Dan Price Book Value (PBV) Untuk Pengambilan Keputusan Investasi. Duke Law Journal, 1(1), 1-13. https://doi.org/10.1017/CBO9781107415324.004

Permata, I. S. K. dan T. (2017). Penilaian Saham Dengan Menggunakan Metode Price Earning Ratio (PER) dan Price Book Value (PBV). Jurnal Administrasi Bisnis (JAB), 2(1), 65-73.

Ramadhani, H. (2016). Analisis Price Book Value dan Return On Equity Serta Deviden Payout Ratio Terhadap Price Earning Ratio (Studi Pada PT. Bank Mandiri Tbk). Forum Ekonomi, 18(1), 34-42.

Riyondi, Y. W. (2017). Analisis Fundamental Perusahaan Dalam Industri Semen Yang Terdaftar Di Bursa Efek Indonesia ( Bei ). 2.

Rusliati, E. (2017). Harga Saham Dengan Metode Dividend Discount Model Dan Price To Book Value. 10(2), 1-10.

Suselo, D., Djazuli, A., \& Indrawati, N. K. (2015). Pengaruh Variabel 
Fundamental dan Makro Ekonomi Terhadap Harga Saham (Studi pada Perusahaan yang Masuk Dalam Indeks LQ45). Jurnal Aplikasi Manajemen (JAM), 13(1), 104-116. Retrieved from http://jurnaljam.ub.ac.id/index.php/jam/article/view/734\%0Ahttp://www.jur naljam.ub.ac.id/index.php/jam/article/view/734

Utomo, W., Andini, R. dan, \& Raharjo, K. (2016). Pengaruh Leverage (DER),Price Book Value(PBV), Ukuran Perusahaan (Size), Return On Equity(ROE), Deviden Payout Ratio(DPR) Dan Likuiditas (Cr) Terhadap Price Earning Ratio (PER) Pada Perusahaan Manufaktur Yang Listing Di Bei Tahun 2009 - 2014. Journal Of Accounting, 2(2).

Wijaya, A. (2015). Analisis Fundamental Dengan Pendekatan Dividend Discount Model(DDM) Untuk Menilai Kewajarah Harga Saham (Studi pada Perusahaan Sub Sektor Semen yang Terdaftar di Bursa Efek Indonesia Periode 2011-2013). Jurnal Administrasi Bisnis S1 Universitas Brawijaya, 26(2), 1-7.

Winata. (2017). Analisis Fundamental Untuk Menilai Kewajaran Harga Saham Dengan Pendekatan Price Earning Ratio (PER)Dan Price To Book Value (PBV)(Studi Pada Perusahaan Consumer Goods yang Terdaftar di Indeks Saham Syariah Indonesia Periode 2016). 90-91.

Wulandari, R. dan N. (2016). Analisis Fundamental Menggunakan Pendekatan Price Earnings Ratio Untuk Menilai Harga Intrinsik Saham Untuk Pengambilan Keputusan Investasi Saham (Studi pada perusahaan yang sahamnya masuk indeks LQ45 Periode tahun 2010-2012 di Bursa Efek Indonesia). Jurnal Administrasi Bisnis S1 Universitas Brawijaya, 31(1), 7380 . 